\title{
Inclusive Health Care Access of Shackling-Free Program
}

\author{
Devi Eka Ariyani, Kristina Setyowati \\ Faculty of Social and Political Sciences \\ Sebelas Maret University \\ Surakarta, Indonesia \\ ariyanidevi@student.uns.ac.id, krist_uns@yahoo.co.id
}

\author{
Rutiana D Wahyunengseh \\ Department of Public Administration \\ Sebelas Maret University \\ Surakarta, Indonesia \\ rutians.uns@gmail.com
}

\begin{abstract}
This journal discussed about the experience in conducting research of access to inclusive health care services in Ponorogo Regency. In this research, the used theory of access is the concept from Anderson, 1980. Access to health care services for people with schizophrenia is very influenced by predisposing factors, supporting factors, and need factors toward health care services. It relates to the demographical characteristics, sociocultural system, and the trust to health care services. In addition, the economic conditions, the availability of health care facilities, the quality of services, the availability of resources and the accessibility of health care facilities are also influenced access to health care services. The purpose of this research is to analyze the inhibiting factors and the supporting factors of access to inclusive health care services in shackling-free program. This research was used qualitative approach. The data was collected with observation, documentation, and in-depth interview method, while the data was analyzed in descriptive-analytical process.
\end{abstract}

Keywords-access; inclusive health care services; schizophrenia or people with mental disorders (ODMK); shacklingfree program

\section{INTRODUCTION}

Access to mental health services is currently one of the crucial problems around the world, including Indonesia [1]. In health care services, access is defined as the opportunity to reach and obtain appropriate health care services in situations of perceived need for care [2]. The importance of this access is considered to prevent the attempts of shackling and eliminate the negative stigma towards people with schizophrenia in order to obtain health care services as explained in Act 18 of 2014 about Mental Health in which mental health services need acts of promotive, preventive, curative, and rehabilitative. It is to implement interest and equality- oriented services of every citizen in obtaining services which tend to have different subjective characteristics including people with special care, such as the disabled, elderly people, pregnant women, children, and people with mental disorders [3]. Thus, the implementation of new public services which known as the existence of citizen charter is needed by the implementation of inclusive services. The concept of inclusive services includes three major dimensions of quantity, quality, and accessibility [4]. This concept shows that the inclusive services should be high amount (quantity), sustainable (good quality), and equitable distribution (accessibility).
Today, there are approximately $70 \%$ of world population suffering mental disorders $[5,6]$. While, according to WHO in 2016, there are approximately 35 million people with depression, 60 million people with bipolar disorders, 21 million people with schizophrenia, and 47,5 million people with dementia. In Indonesia, according to the data of 33 mental hospitals around Indonesia, there are approximately 2,5 million people with schizophrenia $[7,8]$. Schizophrenia is a psychotic disorder characterized by major disorder of mind, emotion, behavior, distracted mind in which some thoughts are not logically interrelated with wrong perception and interest, equitable or unsuitable affect, and many kinds of bizarre motoric activity disorder (abnormal behavior). Schizophrenia is defined as the neurological disease that affects a person's perception, thinking, language, emotion, and social behavior [9].

According to Health Research Database 2013 about Mental Health, the prevalence of emotional mental depression by depression and anxiety from people above 15 years reaches to 14 million people or approximately $6 \%$ of total population in Indonesia. While, prevalence of severe disorder, for example schizophrenia, are approximately 400.000 people or 1,7 of 1000 population in Indonesia. Some general factors of schizophrenia, such as economics factors, cultural factors, genetic factors, and family factors.

Wide concerns on the lack of qualified access to mental health care is represented by great supports for mental health commission $[10,11,12]$. The research on access to health care services has been conducted by [13]. The poor quality of access to mental health services for people with schizophrenia is influenced to the poor quality of system of mental health services in which been susceptible to violation case of rights towards people with schizophrenia $[14,15]$. This phenomenon has more been worse with the news from several foreign medias which described about mental health services in details. The news includes The Sydney Morning Herald which airing the news entitled "The Face of Indonesia's Shame" on June 2010. One year then, PBS News Hour was also airing the news entitled "Indonesia's Mentally Ill Face Neglect: Mistreatment" on July 2011 [16]. It shows that the program of mental health services has not totally been optimal [17].

Several problems of this unoptimized access to health care services for people with schizophrenia in Indonesia, includes 
most of shackling people with mental disorders having no resident identity card (KTP) and unoptimized system of mental health insurance [18], high stigma from society towards people with mental disorders and unleaving punishment of shackling, exclusive behavior of the family towards the organizer team of mental health services, unavailable rehabilitation process in the society for the former sufferer, unavailable expertise consultant (psychiatry) [19], lack of health services in rural areas, and unachievable health care facilities for some people by its fardistance location from the regency and province [18]. It is also based on the researches [20] which stated that access to services is impaired with culture or belief of the society about people with schizophrenia as people possessed by demons, got black magic or been dangerous to their surroundings.

Those several problems of access finally made the family of people with schizophrenia choosing to shackle, isolate, and chain their family members with mental disorder [21]. The shackling program can be considered as the inhuman act and violation of human rights, includes the rights of earning income, getting education or job, and having social life $[10,11,12]$

One of the Government's solutions in overcoming the issue of mental health care towards practice of shackling especially Indonesia where the Government has instructed for Indonesia is shackling-free program on 2014. This program aims to eliminate the existence of shackling and neglecting practice toward mental disorder. It has been joining by 32 of 34 provinces, including East Java Province.

Ponorogo Regency is known as a pioneer or the first sample of shackling-free program in the East Java releasing by Governor of East Java, Soekarwo, in 2012 with a symbolization of people with schizophrenia which held at Kemuning Village, Subdistrict of Sawo, Ponorogo Regency. Based on the data of the Department of Health, Ponorogo Regency, the number of shackling in people with schizophrenia was known as many as 126 people in 2012.

Indonesia's shackling-free program is in accordance with the Governor's Regulation on Number $460 / 11166 / 031 / 2014$ about the freedom for people with schizophrenia as the sufferers of shackling which the strategic ways are (1) issued the Resident Identification Number (NIK) of the sufferers, (2) optimized the health center by establishing subsidiary health center for mental health (PUSTU), (3) unionized and optimized organizer team of mental health services for society (TPKJM).

This shackling-free program in Ponorogo Regency has been conducting for two years, but it has not been optimal. It is because based on the data of Department of Health in 2017 from the total number of 126 people with schizophrenia, there are 90 people healed with access to mental health services and other 30 people are still forced to be shackled by their family without any access to mental health services.

Several problems related to mental health services in Ponorogo Regency includes the unavailability of psychiatry [22], the termination of Memorandum of Understanding (MoU) between RSUD Dr. Harjono and RSJ Menur in
Surabaya since the beginning of 2015 [23], the unavailability of 10 bed for in-patient at type B hospital or local hospital in Ponorogo Regency (Interview with the Head of Health Care Services at Department of Health on Tuesday, December 4, 2016), the unoptimized in-patient room for people with schizophrenia by its limited number of medical staff (Interview with the Head of Health Care Services at Subsidiary Mental Health Center of Paringan, Monday, December 3, 2016), the special health center for mental health services is not serving people with schizophrenia otherwise for general patients only [23]. In addition, it is also because the lack of cross-sector cooperation with department of social for rehabilitation which has been a place of rehabilitation for people with schizophrenia managing voluntarily [23]. Based on that identification of problem, this research is focused on inclusive access to health care services in shackling-free program by analyzing it supporting and inhibiting factors for health care services.

\section{THEORETICAL}

Access is defined as the opportunity to reach and obtain appropriate health care services in situations of perceived need for care [2] and deliver satisfied health care services in relation to the needs. Access is considered as the result of relationship between characteristics of household, social and physical environment and characteristics of health delivery system, the organization, and the providers. Access to health care services should also use the dimensions of people, place, providers, and payment [24]. Access theory of Aday as a theory used in this research to analyze access to health care services which comprehensively examines about access to health care services on supply, demand, and health policy. This theory describes the relationship between several components in influencing one another which can be seen in the following figure [25]:

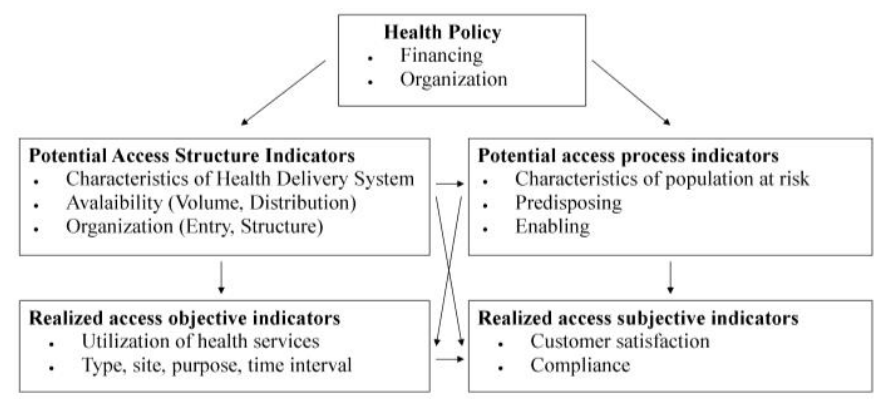

Source: Aday,LA,Andersen, R,Fleming G.V.1980

Fig. 1. Framework Study Access

Access is the indicator of compliance for health care services which can be measured by four categories, such as potential access structure indicators, potential access process indicators, realized access objective indicators, and realized access subjective indicators [26]. First, potential access structure indicators consist of three types [26], those are characteristics of health delivery system, availability, and organization. The characteristics of health delivery system includes ownership and types of health care services. The availability of health care services can be seen from the number 
of facilities of health care services and the number of medical staffs in certain areas. While, organization of health care services can be measured by entry and structure of health delivery system. Secondly, potential access process indicators give description for characteristics of society from three factors, such as predisposing factors (knowledge, behavior, benefit of health care services, etc.), enabling factors (membership of health insurance, residence, etc.), and need factors based on patient's perception and medical characteristics. Thirdly, realized access objective indicators can be seen from the utilization of health services. Fourthly, realized access subjective indicators can be seen from customer satisfaction towards health services [26].

\section{METHOD}

This research was used descriptive-qualitative towards access to health care services based on its supporting factors and inhibiting factors in shackling-free program. It was held in Ponorogo Regency, East Java, Indonesia. The source of data was taken from primary and secondary data. The primary data were collected by using interview and observation. The informants of this research was taken by purposive sampling in which they have enough knowledge and participate in shackling-free program in Ponorogo Regency. While, secondary data were collected from relevant documents of shackling-free program in Ponorogo Regency. For its valid data, this research was used triangulation of source. Triangulation of sources was done by collecting data from different sources with the same method. The data were analyzed by using interactive analysis, i.e. the reduction of irrelevant data to the problem, data display for presenting data in table, related pictures, and conclusion as the final result of the objective of research.

\section{RESULT AND DISCUSSION}

The shackling-free program can be considered as the inhuman act and violation of human rights which is contrary to UUD 1945 on section 28 of article 1, UU 39 of 1999 [27] about Human Rights on section 42, UU 36 of 2009 about Health on section 148 of article 1 [28], and also supported by UU 18 of 2014 about Mental Health [29]. UU 18 of 2014 is instructed that mental health services need acts of promotive, preventive, curative, and rehabilitative. Mental health delivery system is systematically accomplished in stages from primary mental health services, main health center, and psychiatry center. In overcoming the problem of shackling towards people with schizophrenia in society, there must be a health program. The kind of mental health services is certainly different in every country. The health program has a different context in Kanda Case in which the program is in the kind of deinstitutionalization, while Nigeria used TIK in its primary health care services for rural society. The kind of health reformation with insurance program was used in the United States [30], while India was used training program on mental health for rural medical staffs [5]. The kind of partnership for emergency unit was used in California [31], the program of healthy city was used in New Zealand [32], and the Government of Indonesia itself was promoted Indonesia's shackling-free program.
Access to health care services of shackling-free program in Ponorogo Regency has not been optimal because there are still 30 people forced to be shackled. In the preliminary research survey found that negative stigma towards people with schizophrenia are still existed in the society. It can be the inhibiting factors for access to health care and also majority of family from people with schizophrenia working as the farmers in which they are often less able to pay the cost of services if without any health insurance and the inaccessible location of hospital for health care services. This problem to access in Ponorogo Regency is very relevant to the theory from Aday Andersen, in which access to services is tend to be different in using primary health care services [25]. The existence of predisposing factors such as demography, social structure, and trust. Some important characteristics such as individual, cultural, and trust are more varied for rural population. It can also be considered as one of the inhibiting factors, especially if the characteristics between providers of services and patients are different, such as the varieties of culture and ethnic. However, the characteristics of society based on their living location is not necessarily the inhibiting factors of access. For example, social factor of the society allows them for a better access [24]. In addition, the place is also the very influential to utilization of access in which geographical location of the residence can be the inhibitor for access to health care services. The difference in demographical obstacles, such as mountain area than a flat area and blizzard weather than sunny weather. In increasing of inhibitor of journey, the accessibility will be decreased. Secondly, enabling factor, health care services can be reached if there is an insurance of services, affordable cost, accessible health center, and also need factor as the third factor. It also explained by [33] that access to health care in Montreal is influenced by international law. The norms of international law contains about health care. Access to health care is guaranteed by the health insurance. Principally, access to health care is a social right which means the authorities has a wide authority to decide about how and when the social rights will be realized. Health insurance can be defined as the rights for social security in which access to health care services is based on the concept of solidarity and equality for everyone. In contrast to [34], it shows that there is a difference in accessing health care services between mountain area and central area. It is because the quality of service for people with schizophrenia in mountain area is lower than central area. Health status in a mountain area is included in low category which can be seen from the number of mortality by complication towards people with schizophrenia. The level of inequality of health care services around the world is almost the same which is related to the geographical location and lack of resource.

\section{CONCLUSION}

The health program should be concerned on monitoring health status and quality and basic services for marginalized groups in the range of services. The inequality of accessing health care services program should be more evaluated by the leader of program in order to reach the equality and improvement of health care services for society. Several factors of poor people becoming less healthy include daily life, social and economic gaps, and perception of society in measuring and responding toward inequality of access to health care services. 
Access to health care services for people with schizophrenia is influenced by predisposing factors, supporting factors, and need factors toward health care services. It is related to demographical characteristics, sociocultural system, and trust toward health care services. In addition, economic condition, the availability of health care facilities, the quality of services, the availability of resource and the accessibility of health care facilities are also influenced access to health care services.

\section{REFERENCES}

[1] Ministry of Health, National Health System, Jakarta, 2009.

[2] Haddad S, Utilisation des services de santé en pays en développement: une étude dans la zone rurale de Nioki au Zaïre., France: Université Claude Bernard Lyon, 1992

[3] D. Agus, Manajemen Pelayanan Publik: Peduli, Inklusif dan Kolaboratif, UGM Press. Yogyakarta. 2011.

[4] Verdier, Concept and measure of inclusive health across countries. African Development Bank, Abidjan,Cote d'ivoire Working paper series n, 2016.

[5] Sahoo, S. \& Khess, Prevalence of Depression, Anxiety, and Stress among Young Male Adults in India: A Dimensional and Categorical Diagnoses-based Study. Journal of Nerve and Mental Disesase. 2010.

[6] Wittchen, H. U., Jacobi, F., Rehm, J., Gustavsson, A., Svenddon, M., Jansson, B., The Size and Burden of Mental Disorders and Other Disorders of the Brain in Europe. Journal Europe Neuro Psychopharmacology. 2011.

[7] WHO, International Journal of Health Care Quality Assurance. Highlight Global Under Investment in Mental Health Care. 2016.

[8] Maslim, R, Prevalensi dan Distribusi Masalah Kesehatan Jiwa di Indonesia, UGM. Yogyakarta. 2012.

[9] Yosep, I, Keperawatan Jiwa. Edisi 2. Refika Aditama, Bandung. 2009.

[10] Yin-Har Lau, Annie, Michael Ridge "Addressing the impact of social exclusion on mental health in Gypsy, Roma, and Traveller communities", Journal Mental Health and Social Inclusion, Vol. 15 Iss: 3, 2011, pp. $129-137$

[11] R. Sebastian, "New governance, new hope: findings and results of the taskforce to establish a Mental Health Commission for NSW", Mental Health Review Journal, Vol. 17 Iss: 4, 2012, pp.248 - 259

[12] P. R. Rachel and Julie Challenging Discrimination within Mental Health Service: The Importance of Using Lived Experience in the Workplace. Journal Mental and Social Inclusion, 2014.

[13] Gurhan, N., Ugurlu, N., \& Kaya, B, Access of Discharged Schizophrenia Patients to Employment and Association Memberships in Turkey. Hospital Practices and Research, 2016.
[14] Becker, A. E., Arthur K., Mental Health and the Global Agenda. New England Journal Medicine, 2013.

[15] A. I. Ibukun, and A. A. Adegbohun, Experiences of Discrimination by People with Schizopherenia in Lagos, Nigeria. Journal of Public Mental Health. 2014

[16] www .lautanopini.wordpress.com/ Shackling-Free Program, accessed on date 2 january 2018

[17] W. Lestari and W. Y. Fauzia, Stigma dan Penanganan Penderita Gangguan Jiwa Berat yang Dipasung. ;157-66. 2014.

[18] Minas H, The Lancet, 374 (9690) pp. 592-3. Mentally Ill Patients Dying in Social Shelters in Indonesia. 2009.

[19] W. Danar, Penderita Sakit Jiwa di Jawa Tengah Masih Tinggi. 2015.

[20] Tyas, T. H., Thesis Master. Pasung: family experience of dealing with "the deviant" in Bireuen, Nanggroe Aceh Darussalam, Indonesia, University of Amsterdam. Amsterdam. 2008.

[21] Idaiani, S. \& Raflizar, Buletin Penelitian Sistem Kesehatan. Faktor yang Paling Dominan terhadap Pemasungan Orang dengan Gangguan Jiwa di Indonesia (Factors Contributing to Shackling Practice of Psychotic People in Indonesia). 2015.

[22] The Jawa Pos Institute of Pro-Otonomi, available at: http;//www.jpip.or.id

[23] Dewan Perwakilan Rakyat Daerah Kabupaten Ponorogo, available at: http://www/dprd-ponorogo.go.id

[24] MacKinney, Access to Rural Health Care - A Literature Review and New Synthesis. USA: Rural Policy Research Institute. 2014.

[25] Aday, L. A., \& Andersen, R. Fleming, G.V, 1980. Health Care in the US, Equitable for Whom?, Sage Publications, Beverly Hills. London.

[26] R. Ekowati, Akses Layanan Kesehatan, PT. Raja Grafindo Persada. Jakarta. 2013

[27] UU 39 of 1999 about Human Rights

[28] UU 36 of 2009 about Health

[29] UU 18 of 2014 about Mental Health

[30] Garfield, R. L., Druss, B. G., Health reform, health insurance, and mental health care. Am. J. Psychiatry. 2012, 169:675-677

[31] Brown T. T., The Impact of California's Full Service Partnership Program on Mental Health Related Emergency Department Visits. Psychiatric Services 63(8), 802-807, 2012.

[32] K. Nour, Evaluation Of The Effects Of Health Impact Assessmen Practice At The Local Level In Monteregie. Health Res Policy Syst. 14: 7. 2016.

[33] Vanasse A., Assessing spatial accessibility to mental health facilities in an urban environment. Spatial and Spatio-temporal Epidemiology 3(3):195-203, 2011

[34] Pettit, A. R., and Marcus, S. C., Expanding Patient Access to Quality Medication-related Information: The Potential of Medication Hotlines to Improve Patient Adherence in Schizophrenia. Social Psychiatry and Psychiatric Epidemiology, 2015. 